\title{
Effect of Different Fertilization Treatments on the Biodiversity of Mites Associated with Tomato Plants and its Yield in Fayoum Governorate, Egypt
}

\author{
Reham I. A. Abo-Shnaf*; A. Y. Zaki*; A. I. Aly ${ }^{* *}$ and M. M. Mergawy ${ }^{* * *}$ \\ *Vegetable and Aromatic Plant Mites Dept., Plant Prot. Res. Inst., Agric. Res. Cent.. Dokki. Giza. Lgypt. \\ ${ }^{* *}$ Vegetable Res. Dept., Horticulture Res. Inst., Agric. Res. Cent., Dokki. Giza, Fgypt. \\ ${ }^{* * *}$ Central Laboratory of Organic Agriculture, Agric. Res. Cent., Giza, Egypt.
}

\begin{abstract}
A field experiment was conducted on tomato plants, hybrid (010) at Ibshway, Fayoum governorate, Egypt in winter season (2014-2015). Three replicates were used to study the interaction effects of different organic manures [compost. chicken manure and farmyard manure, and three potassiumlevels $\left(\mathrm{K}_{0}, \mathrm{~K}_{1}, \mathrm{~K}_{2}\right.$ liquid potassium $\left.\left.38 \%\right)\right]$ on the biodiversity of mites and the yield of tomato. Random samples of debris. litters and soil are collected every ten days intervals from November 2014 to January 2015. The results revealed 33 species of 27 genera in 21 families from Astigmata, Prostigmata, Mesostigmata and Cryptostigmata. Famiy Scutacaridae ranked the first in populations followed by Family Haplozetidae. The effect of three levels of organic fertilizers was recorded. The interaction effects between organic manures and potassium levels on tomato y ield also were discussed.
\end{abstract}

Key words: Mites; Biodiversity; Organic fertilizers; Tomato.

\section{INTRODUCTION}

Tomato (Solanum lycopersicum L.; Solanaceae) is considered one of the most important vegetable crop grown in Egypt for its local consumption and exportation. Tomato can be grown on a small scale in the kitchen garden, and also in a commercial scale as a cash crop. One of the basic methods to improve tomato yield and fruit quality is the cultivar production and evaluation. Yearly, there are many recommendations for new cultivars and hybrids. Several studies proved that nitrogen has a marked effect on vegetative characteristics of tomato plants. The application of organic manure in fertilization system in tomato plantations provide the nutritional requirements of plants and also suppress the plant pest's populations. Many researchers and practicing farmers observed that fertility practices replenish and maintain high soil organic matter and enhance diversity of soil macro and microbiota and provide an environment that through various processes enhances plant health (McGuiness, 1993).

Oribatid mites (Acari: Oribatida) are widely distributed around the world, playing a biological role of great importance in both natural and agricultural ecosystems. They form the main part of soil microarthropods and play an important role in several soil processes, such as organic matter decomposition, material and energy cycles and soil formation. They also act as vectors of numerous parasites; as a dominant component of soil organisms, and are obviously suitable bioindicators (Peterson and Luxton, 1982; Lee and Pankhurst, 1992 and Haq, 1994).

Soil mites are abundant organisms and sensitive to soil perturbations in agricultural practices and their numbers and diversity often get reduced affecting their ecosystem services (Minor and Cianciolo, 2007). Several soil mite genera are considered good bio-indicators of habitat and soil conditions (BehanPelletier, 1999). The soil biota complements each other in commutation of litter, mineralization of essential plant nutrients and conservation of those nutrients within the soil system (Marshall, 2000).

The objective of this paper is to evaluate the interaction effects between different organic manures treatments and liquid potassium levels on the biodiversity of mites inhabiting tomato plants as well as the tomato yield in Fayoum governorate, Egypt.

\section{MATERIALS AND METHODS}

\section{a. Experimental design:}

The present investigation was conducted at Ibshway, Fayoum governorate during the winter season, 2014-2015. Seeds of tomato (Solanum lycopersicum L.; Solanaceae) (hybrid 010) produced by Sengenta company was sown in seedling trays in a greenhouse on August 10-13, in 2014. A spilt plots design with three replicates was used. Organic fertilizers were applied in the main plots and potassium levels were applied in the sub plots. During soil preparation, calcium supper phosphate $(15.5 \% \mathrm{P} 2 \mathrm{O} 5)$ at the rate of $46.5 \mathrm{~kg} / \mathrm{fed}$ was used (fed. $=$ Feddan $=4200$ square meter). Three organic manures [compost, chicken manure and farm yard manure (Fym)] were separately mixed with the soil surface in a rate of 2.5 ton/fed. for each replicate and standard fertilization (control). Tomato seedlings were transplanted in the experimental field after 20 days in rows of $1.0 \mathrm{~m}$ wide and $3.0 \mathrm{~m}$ long with intra row spacing of $50 \mathrm{~cm}$. The organic nitrogen unit $120 \mathrm{~kg} / \mathrm{fed}$ were applied after 15, 30 and 50 days from 
transplanting in each plot. Three liquid potassium $38 \%$ with levels of $\mathrm{K} 0(0 \mathrm{~L} / \mathrm{fed}), \mathrm{K} 1(8.5 \mathrm{~L} / \mathrm{fed}), \mathrm{K} 2$ $(17 \mathrm{~L} / \mathrm{fed})$ were sprayed after 21 days from transplanting. In each experimental unit, plants of the two outer rows were assigned to measure their effects on mite biodiversity.

\section{b. Samples collection:}

Observations were performed in different fertilization treatments. In each treatment, random samples of debris, litters and soil were collected periodically at ten days intervals from November 2014 to January 2015. These samples weighing approximately $0.25 \mathrm{~kg}$, were kept immediately in polyethylene bags, and brought to the laboratory for extraction by Berlese funnel (Krantz and Walter, 2009). The extracted mites were mounted in Hoyer's medium. After a cover slide had been placed, the slides were placed on a hot plate for two weeks. Name of region, host plant, collecting date were written on labels and stuck on the slides. Specimens of phytophagous, predacious and other mites of miscellaneous feeding habits were identified to species level using a microscope and referring to the key of taxonomic references cited by Zaher (1986), Smiley (1992), Krantz and Walter (2009), Abo-Shnaf et al. (2013) and Abo-Shnaf \& Moraes (2014).

\section{c. Species diversity:}

The biodiversity of collected soil mites were estimated by using equilibrium. Diversity of collected mites was determined for samples pooled over one summer season by two different patterns of fertilization. It was measured by diversity index that reflected to the number of species (richness) in the samples. Two common indices were computed, Shannon-Wiener index "H" and Simpson index "S". They were calculated as described by Ludwig and Reynolds (1988).

$$
H^{\prime}=-\Sigma(n i / n) \ln (n i / n) \text { and } S=\Sigma(n i / n)^{2},
$$

where " ni" is the number of individuals belonging to the $i^{\text {th }}$ of "S" taxa in the sample and " $\mathrm{n}$ " is the total number of individuals in the sample. " $\mathrm{H}$ " is more sensitive to changes in number of species and diversity, while "S" is a dominance index gives more weight to common or dominant species (Ludwig and Reynolds, 1988); it highly suggests that the two individuals drawn at random from the population belong to the same species. If the result is high then the probability of both individuals belonging to the same species maybe high, as a result the diversity of the community samples might be low.

\section{d. Statis tical analys is:}

Analysis of variance was conducted to determine the significance between means of males, females and immatures structure in addition to tomato yield. All collected data were statistically analyzed according to the technique of analysis of variance for split-plot design by "MSTAT-C" computer software package. The differences among treatment means were compared by LSD test at $\mathrm{P} \leq 0.05$ (Gomez and Gomez, 1983).

The first, second and third harvesting were respectively on November 11,25 and December 2 . 2014, fruits from each plot were collected, weighed and recorded. At the end of experimental period, data of the previous plots were collected and subjected to statistical analysis.

\section{RESULTS AND DISCUSSION}

\section{Mite species richness:}

Table (1) showed that the mite species inhabiting debris, litters and soil underneath tomato plants at Fayoum governorate included 33 species of 27 genera belonging to 21 families in different mite suborders. The families are: Acaridae (Astigmata); Bdellidae, Caligonellidae, Cunaxidae, Eupodidae, Rhagidiidae, Scutacaridae, Siteroptidae, Tetranychidae and Tydeidae (Actinedida); Ameroseiidae, Laelapidae, Macrochelidae, Ologamasidae, Pachylaelapidae, Parasitidae, Phytoseiidae and Uropodidae (Gamasida); in addition to Haplozetidae and Oppuidae (Oribatida). The mite species are classified into three groups according to their habitat:

\section{a- Mite collected from debris:}

This group occurs on leaves, debris and those are included two species: Tetranychus urticae Koch and Petrobia spp. (Tetranychidae).

\section{b- Mite collected from litters:}

This group occurs only in debris underneath tomato plants and included 27 species such as: Neoseiulus barkeri Hughes (Phytoseiidae); Tydeus kochi Oudemans (Tydeidae); Androlaelaps aegypticus Hafez, El-Badry \& Nasr; A. casalis (Berlese); Hypoaspis koseii Hafez, El-Badry \& Nasr, H. orientalis Hafez, El-Badry \& Nasr; H. petrovae Shereef \& Afifi; Laelaspis astronomicus (Koch) (Laelapidae); Parasitus zaheri Hafez \& Nasr, Vulgarogamasus spp. (Parasitidae); Coleoscrius tuberculatus Den Heyer; Cunaxa capreolus (Berlese);Cunaxa spp.; Neocunaxoides andrei (Baker \& Hoffmann) (Cunaxidae); Eupodes temperatus Shiba, (Eupodidae); Spinibdella bifurcata Atyeo, (Bdellidae); Ameroseius wahabi (Ibrahim \& AbdelSamed); A. zaheri (El-Badry, Nasr \& Hafez) (Ameroseiidae); Macrocheles merdarius (Berlese) (Macrochelidae); Caligonella humilis (Koch) (Caligonellidae); Trichouropoda spp. (Uropodidae); Siteroptes spp. (Siteroptidae); Heterodispus chanti (Scutacaridae); Pachylaelaps aegypticus Hafez 
Table 1: Richness of mite species inhabiting tomato plants under effects of different manure treatments from September 2014 to January 2015.

\begin{tabular}{|c|c|c|c|c|c|c|c|c|c|c|c|c|c|c|}
\hline \multirow{2}{*}{ Family } & \multirow{2}{*}{ Species } & \multicolumn{3}{|c|}{ Compost manure } & \multicolumn{3}{|c|}{ Chichen manure } & \multicolumn{3}{|c|}{ Animal manure } & \multicolumn{3}{|c|}{ Standard } & \multirow{2}{*}{ fota } \\
\hline & & $\mathrm{KO}$ & KI & $\mathrm{K} 2$ & KO & $\mathrm{kl}$ & $\mathrm{K} 2$ & $\mathrm{kO}$ & Kl & $\mathrm{K} 2$ & ho & $\mathrm{KI}$ & $k 2$ & \\
\hline Acaridae & Tyrophagusputrescentiae & 0 & 16 & 12 & 2 & 38 & 7 & 15 & 16 & 6 & 1 & 25 & 25 & 163 \\
\hline Haplozet idae & Xylobates souchnaiensis & 88 & 127 & 94 & 40 & 84 & 60 & 98 & 75 & 71 & 79 & 49 & 30 & 895 \\
\hline \multirow{2}{*}{ Oppiidae } & Oppia concolor & 34 & 59 & 23 & 6 & 126 & 20 & 20 & 17 & 24 & 10 & 23 & 14 & 376 \\
\hline & O. sticta & 28 & 30 & 37 & 9 & 17 & 20 & 22 & 15 & 68 & 10 & 22 & 11 & 289 \\
\hline \multirow{2}{*}{ Ameroseiidae } & Ameroseius wahabi & 0 & 0 & 0 & 0 & 0 & 0 & 0 & 0 & 0 & f) & 0 & 1 & 1 \\
\hline & Ameroseiuszaheri & 6 & 1 & 6 & 4 & 14 & 23 & 20 & 12 & 2 & 2 & 2 & 5 & 97 \\
\hline \multirow{6}{*}{ Laelapidae } & Androlaelaps aegypticus & 16 & 20 & 13 & 14 & 22 & 21 & 39 & 22 & 13 & $\pi$ & 17 & 7 & 215 \\
\hline & Androlaelaps casalis & 0 & 0 & 0 & 0 & 0 & 1 & 0 & 0 & 0 & 0 & 0 & 0 & 1 \\
\hline & Hypoaspis koseii & 0 & 0 & 0 & 0 & 0 & 0 & 0 & 0 & 0 & 1 & 0 & 0 & 1 \\
\hline & Hypoaspis orientalis & 0 & 0 & 0 & 0 & 0 & 0 & 0 & 0 & 0 & 4 & 0 & 0 & 4 \\
\hline & Hypoaspispetrovae & 0 & 0 & 0 & 0 & 0 & 0 & 0 & 0 & 0 & 0 & 0 & 1 & 1 \\
\hline & Laelaspis astronomicus & 3 & 0 & 2 & 0 & 0 & 0 & 1 & 0 & 0 & $\mathrm{l}$ & 0 & 0 & 7 \\
\hline Macrochelidae & Macrocheles merdarius & 0 & 0 & 3 & 0 & 9 & l & 1 & 1 & 0 & () & 0 & 0 & 15 \\
\hline Ologamasidae & Gamasiphis pulchellus & 17 & 22 & 12 & 11 & 19 & 10 & 12 & 18 & 19 & 24 & 27 & 8 & 199 \\
\hline Pachylaelapidae & Pachylaelaps aegypticus & 5 & 3 & 8 & 6 & 17 & 5 & 3 & 16 & 12 & 12 & 11 & 10 & 108 \\
\hline \multirow{2}{*}{ Parasitidae } & Parasituszaheri & 1 & 0 & 2 & 0 & 0 & 0 & 0 & 0 & 0 & 2 & 0 & 0 & 5 \\
\hline & Vulgarogamasus spp. & 1 & 0 & 2 & 0 & 5 & 1 & 0 & 0 & () & 0 & 3 & 0 & 12 \\
\hline Phy toseiidae & Neoseinlus barkeri & 4 & 2 & 0 & 0 & 13 & 4 & 1 & 0 & 0 & 0 & 1 & 1 & 26 \\
\hline Rhodacaridae & Multidentorhodacarus aegypticus & 35 & 11 & 0 & 17 & 2 & 4 & 1 & 8 & 7 & 12 & 0 & 4 & 101 \\
\hline Uropodidae & Trichouropoda spp. & 0 & 0 & 0 & 0 & 0 & 0 & 0 & 0 & 3 & 4 & 0 & 0 & 7 \\
\hline Bdellidae & Spinibdella bifurcate & 0 & 2 & 1 & 0 & 5 & 6 & 0 & 3 & 2 & 0 & 0 & 2 & 21 \\
\hline Caligonellidae & Caligonellahmmilis & 0 & 2 & 1 & 0 & 0 & $T$ & 0 & 0 & 0 & 0 & 0 & 0 & 4 \\
\hline \multirow{4}{*}{ Cunaxidae } & Coleoscrius tuberculatus & 3 & 3 & 1 & 2 & 2 & 2 & 6 & 3 & 9 & 3 & 8 & 6 & 48 \\
\hline & Cunaxa capreohs & 0 & 0 & 1 & 0 & 1 & 1 & 0 & 0 & 3 & 2 & 3 & 1 & 12 \\
\hline & Cunaxa spp. & 0 & 0 & 0 & 0 & 0 & 0 & 4 & 0 & 0 & 2 & 0 & 0 & 6 \\
\hline & Neocunaxoides andrei & 0 & 0 & 0 & 0 & 0 & 0 & () & 0 & 1 & 0 & 0 & 0 & 1 \\
\hline Eupodidae & Eupodes temperatus & 2 & 0 & 0 & 0 & 0 & $\mathrm{l}$ & 0 & 1 & 0 & 1 & 1 & 0 & 6 \\
\hline Rhagidiidae & Shibaia shereefi & 0 & 0 & 0 & 0 & 0 & 0 & 0 & 0 & 1 & 0 & 0 & 0 & 1 \\
\hline Scutacaridae & Heterodispus chanti & 124 & 594 & 315 & 153 & 661 & 390 & 723 & 1698 & 668 & 539 & 1178 & 122 & 7165 \\
\hline Siteroptidae & Siteroptes spp. & 0 & 0 & 0 & 0 & 2 & 2 & 0 & 0 & 0 & 1 & 0 & 10 & 15 \\
\hline \multirow{2}{*}{ Tetranychidae } & Petrobia spp. & 0 & 0 & 0 & 0 & 0 & 0 & 1 & 0 & 0 & 0 & 0 & 0 & 1 \\
\hline & Tetranychus urticae & 1 & 1 & 2 & 2 & 1 & 0 & 1 & 1 & 1 & 1 & 0 & 0 & 11 \\
\hline Tydeidae & Tydeus kochi & 0 & 5 & 31 & 0 & 0 & 11 & 3 & 4 & 0 & 1 & 10 & 2 & 67 \\
\hline \multirow{2}{*}{ Total } & & 368 & 898 & 566 & 266 & 1038 & 591 & 971 & 1910 & 910 & 723 & 1380 & 260 & 9881 \\
\hline & & & 1832 & & & 1895 & & & 3791 & & & 2363 & & \\
\hline \multicolumn{2}{|l|}{$\mathrm{K} 0=$ no Potassium } & ium ( & $\%$ & & $\mathrm{~K} 2=$ & $\%$ \%liqu & $\mathrm{dePot}$ & asium & $38 \%)$ & & & & & \\
\hline
\end{tabular}

\& Nasr (Pachylaelapidae); Shibaia shereefi AbouAwad (Rhagidiidae); Gamasiphis pulchellus (Berlease) (Ologamasidae); and Multidentorhodacarus aegypticus Abo-Shnaf, Castilho \& Moraes (Rhodacaridae).

\section{c- Mite collected from soil:}

This group occurs only in soil included four species, Tyrophagus putrescentiae (Schrank) (Acaridae); Xylobates souchnaiensis Abd El-Hamid (Haplozetidae); Oppia concolor Koch and O. sticta Popp (Oppiidae).

\section{Rank abundance of mite families:}

The collected mites were presented by 21 families (Table 1). There are ten families constitute the majority of the total collected mite species i.e: Acaridae, Oppiidae, Haplozetidae, Ologamasidae, Scutacaridae, Ameroseiidae, Phytoseiidae, Rhodacaridae, Laelapidae and Pacheylaelapidae.

The greatest number of collected individuals presented by the Family Scutacaridae (7165 individuals) and ranked the first (72.51\%), followed by the Family Haplozetidae ( 895 individuals) which ranked the second $(9.58 \%)$.

\section{Effect of tested treatments on mite populations: Compost manure:}

Table (1) shows that a small dose of $K_{1}(1 \%$ potassium $38 \%$ ) in plot treated with compost manure increased the abundance of mites to 898 individuals; while those of higher doses of $\mathrm{K}_{2}$ ( $2 \%$ of potassium $38 \%$ ) have only (566 individuals). The families Uropodidae, Rhagidiidae and Siteroptidae were not distinguished in all of those plots treated with compost manure.

\section{Chicken manure:}

Similar results were obtained in the plot treated with chicken manure, where a small dose of $\mathrm{K}_{1}(1 \%$ potassium $38 \%$ ) increased the abundance of mites to 1038 individuals; while higher doses of $K_{2}(2 \%$ of potassium 38\%) significantly decreased this population to 591 individuals; in relation to the plot treated with chicken manure with $K_{0}$ (without 
potassium treated), only 266 individuals were recorded. The families Uropodidae and Rhagidiidae were not distinguished in all of those plots treated with chicken manure.

\section{Farmyard (Fym):}

Also, the same results were obtained in the plots treated with farmyard (Fym), where a small dose of $K_{1}(1 \%$ potassium $38 \%$ ) increased the abundance of mites to 1910 individuals; while higher doses of $\mathrm{K}_{2}$ ( $2 \%$ of potassium $38 \%$ ) significantly decreased this population to 910 individuals; in relation to plot treated with farmyard with $\mathrm{K}_{0}$ (Fym), only (971 individuals) were recorded. Families Parasitidae, Caligonellidae and Siteroptidae not distinguished in all those plots treated with farmyard (Fym).

\section{Standard manure:}

In standard manure, a small dose of $\mathrm{K}_{1}(1 \%$ potassium $38 \%$ ) increased the abundance of mites to 1380 individuals, while higher doses of $\mathrm{K}_{2}(2 \%$ of potassium 38\%) decreased this population to 260 individuals. Standard manure with $\mathrm{K}_{0}$, also decreased this population to 723 individuals. Families Macrochelidae, Caligonellidae and Rhagidiidae were not distinguished in all of those plots.

These results are in agreement with those obtained by Graczyk et al. (2008) who mentioned that a small dose of fertilizer increased the abundance of mites, but higher doses decreased them comparing to the control plots. Also, they are in parallel with that of Moore (1994) who recommended that agricultural practices alert the abundance and dynamics of different organisms and nutrients in soils, and affect the structure and dynamics of whole food webs.

\section{Types of fertilizations affected the mite abundance:}

Family Scutacaridae is the main family found in all plots with higher numbers than other mite families followed by the Family Haplozidae. The obtained results lead to that plots treated with farmyard (Fym) had more mites (3791 individuals) than plots treated with standard manure (2363 individuals) followed by those treated with chicken manure (1895 individua Is ), while the lowest number of mites was found in plots treated with compost (1832 individuals). These results agree with those of Amitai (1992) who mentioned that predatory mites played an important role in suppressing pest population occupying different habitats and used in biological control programs. Members of Phytoseiidae, Laelapidae, Macrochelidae and Stigmaeid are very essential as biological control agents of plant and soil-inhabit ing pest mites, e.g., tetranychids, tenuipalpids and eriophyids (Santos \& Laing, 1985 and Kheradmand et al., 2007).
Table (2) compares the biodiversity of collected mite species underneath tomato plants in different treatments (compost manure, chicken manure, farmyard and standard fertilization) using ShannonWiener " $H$ " and Simpson "S" Indices of diversity. The vegetations of tomato varied in mites richness. The collected mite species in tomato plantations treated with farmyard was the highest (3791 individuals); while those treated with compost manure was the lowest ( 1832 individuals). According to Shannon-Wiener "H" Index, the compost manure (21 species, 18 families) and chicken manure (19 species, 19 families) recorded the highest value (1.51 and 1.51 respectively); while farmyard recorded the lowest value ( 0.88 of 21 species and 18 families). This indicate that compost manure and chicken manure had a higher diversity index; while farmyard had a lower one. Similarly, the values calculated for other manure described the different species diversity index for each group.

According to Simpson Index which reflected the measure of dominance, the plots treated with

Table ((2): Estimation of Shannon-Wiener and Simpson Indices of mite diversity in tomato plants under effects of different manure treatments.

\begin{tabular}{lcccc}
\hline Type of index & $\begin{array}{c}\text { Compost } \\
\text { manure }\end{array}$ & $\begin{array}{c}\text { Chicken } \\
\text { manure }\end{array}$ & $\begin{array}{c}\text { Farmy ard } \\
\text { (Fy m) }\end{array}$ & $\begin{array}{c}\text { Standard } \\
\text { fertilization }\end{array}$ \\
\hline Shannon-Wiener & 1.51 & 1.51 & 0.87 & 1.04 \\
\hline Simpson & 0.36 & 0.45 & 2.87 & 1.02 \\
\hline
\end{tabular}

Table 3: Effect of different organic manure treatments on number of mites and tomato yield.

\begin{tabular}{|c|c|c|}
\hline \multirow{2}{*}{ Treatment } & \multicolumn{2}{|c|}{ Characters } \\
\hline & Mites No. (10 rep) & Yield $\left(\mathrm{kg} / \mathrm{m}^{2}\right)$ (3 rep) \\
\hline \multicolumn{3}{|c|}{ Organic manures } \\
\hline Compost (M1) & 67.52 & $10.07 b$ \\
\hline Chicken (M2) & 69.93 & $\mathrm{I} 2.55 \mathrm{a}$ \\
\hline Farmy ard (M3) & 140.04 & $9.78 b$ \\
\hline Standard (M4) & 86.44 & $9.32 \mathrm{c}$ \\
\hline $\operatorname{LSD}(5 \%)$ & NS & 0.31 \\
\hline \multicolumn{3}{|l|}{ Potassium (K) } \\
\hline $\mathrm{K}_{0}$ & $64.03 b$ & 10.38 \\
\hline $\mathrm{K}_{1}$ & $145.00 \mathrm{~A}$ & 10.47 \\
\hline $\mathrm{K}_{2}$ & $63.92 b$ & 10.44 \\
\hline $\operatorname{LSD}(5 \%)$ & 58.46 & $\overline{N S}$ \\
\hline \multicolumn{3}{|l|}{ Interaction } \\
\hline $\mathrm{M} 1 \times \mathrm{K} 0$ & 40.44 & 10 \\
\hline $\mathrm{M} 1 \times \mathrm{K} 1$ & 99.78 & 10.11 \\
\hline $\mathrm{M} 1 \times \mathrm{K} 2$ & 62.33 & 10.11 \\
\hline $\mathrm{M} 2 \times \mathrm{K} 0$ & 29.56 & 12.45 \\
\hline $\mathrm{M} 2 \times \mathrm{K} 1$ & 115 & 12.71 \\
\hline $\mathrm{M} 2 \times \mathrm{K} 2$ & 65.22 & 12.49 \\
\hline $\mathrm{M} 3 \times \mathrm{K} 0$ & 107.22 & 9.74 \\
\hline $\mathrm{M} 3 \times \mathrm{K} 1$ & 212.22 & 9.74 \\
\hline $\mathrm{M} 3 \times \mathrm{K} 2$ & 100.67 & 9.85 \\
\hline $\mathrm{M} 4 \times \mathrm{K} 0$ & 78.89 & 9.31 \\
\hline $\mathrm{M} 4 \times \mathrm{K} 1$ & 153 & 9.33 \\
\hline $\mathrm{M} 4 \times \mathrm{K} 2$ & 27.44 & 9.32 \\
\hline $\operatorname{ISD}(5 \%)$ & NS & NS \\
\hline
\end{tabular}


farmyard maintained the highest number of dominant species of value of 2.87 and recorded (3791 individuals) of scutacarid mites.

\section{Statis tical analys is :}

Statistical analysis proved that no significant differences were observed not only between means of different manure treatments, but also in interaction effects between organic manures and potassium treatments; while a high significant differences were observed between means of potassium treatments (Table 3). Application of organic manure alone indicated that chicken manure caused a significant increase of tomato yield (12.55 Ton/fed.) followed by compost ( 10.07 Ton/fed.) (Table 3 ). These results agree with the results of Olaniyi and Ajibola (2008) who pointed out the application of poultry manure and inorganic nitrogen fertilizer $(60 \mathrm{~kg} / \mathrm{ha})$ significantly increased tomato yield. Potassium had no significant effect. The interaction effects between organic manures and potassium levels on tomato yield had no significant differences, although the highest yield was obtained by chicken manure with $\mathrm{K}_{1}$ potassium level (12.71 ton/fed.).

Finally, chicken manure effects on tomato yield have been supported by the results of mite biodiversity which indicated that chicken manure recorded the highest biodiversity of soil mites (19 species and 19 families).

\section{REFERENCES}

Abo-Shnaf, Reham I. A. and Moraes, G. J. de. 2014. Phytoseiid mites (Acari: Phytoseiidae) from Egypt, with new records, descriptions of new species, and a key to species. Zootaxa, 3865 (1): $1-71$.

Abo-Shnaf, Reham I. A.; Castilho, R. C. and Moraes, G. J. de. 2013. Two new species of Rhodacaridae (Acari: Mesostigmata) from Egypt and a key to the species of the family from the Mediterranean region. Zootaxa, 3718 (1): 28-38.

Amitai, S. 1992. New records of Phytoseiid mites (Acarina: Phytoseiidae) from Cyprus. Entomolgia Hellenica, 10:19-20.

Behan-Pelletier, V. M. 1999. Oribatid mite biodiversity in agroecosystems: role for bioindication. Agriculture Ecosystems Environment, 74: 411-423.

Gomez, K. and Gomez, A. 1983. Statistical Procedures for Agricultural Research. An International Rice Research Institute Book. A Wiley-Interscience Publication, John Wiley \& Sons, New York, 680 pp.

Graczyk, R.; Seniczak, S. and Graczyk, B.W. 2008. The effect of cattle liquid manure fertilization on the soil mites (Acari) of permanent meadow in
Poland. Journal Central European Agriculture, 9 (4): 651-658.

Haq. M. A. 1994. Role of Oribatid Mites in Soil Ecosystem. In: Bhandari. S. C. and Somani, L. L. (Eds.), Ecology and Biology of Soil Organisms, Udaipur: Agrotech Publishing Academy, 143-177.

Kheradmand, K.; Ueckermann, E. A. and Fathipour, Y. 2007. Mites of the genera Zetzellia and Eustigmaeus from Iran (Acari: Stigmaeidae). Acarina, 15 (1):143-147.

Krantz, G. W. and Walter, D. E. 2009. A manual of Acarology. Third edition. Texas Tech University Press, 807 pp.

Lee, K. E. and Pankhurst, C. E. 1992. Soil organisms and sustainable productivity; Australian Journal of Soil Research, $30(6)$ : 855-892.

Ludwig, J. A. and Reynolds, J. F. 1988. Statistical Ecology: A primer methods and computing. A Wiley-Interscience publication, John Wiley \& Sons, New York, 337pp.

Marshall, V. G. 2000 Impacts of forest harvesting on biological processes in northern forest soils. Forest Ecology and Management, 133: 43-60.

McGuiness, H. 1993. Living Soils: Sustainable Alternatives to Chemical Fertilizers for Developing Countries. Consumer Policy Institute, Consumers Union, New York, 411 pp.

Minor, M. A. and Cianciolo, J. M. 2007. Diversity of soil mites (Acari: Oribatida, Mesostigmata) along a gradient of land use type in New York. Applied Soil Ecology, 35:140-153.

Moore, J. C. 1994. Impact of agricultural practices on soil food web structure: Theory and application. Agriculture Ecosystems and Enviroment, 51: 239-247.

Olaniyi, J. O and Ajibola, A. T. 2008. Effects of inorganic and organic fertilizers application on the growth, fruit yield and quality of tomato (Lycopersicon lycopersicum). Journal of Applied Biosciences, 8 (1): 236 - 242.

Peterson, H. and Luxton, M. 1982. A comparative analyses of soil fauna populations and their role in decomposition processes. Oikos, 39 (3): 288-388.

Santos, M. A. and Laing, J. E. 1985. Stigmaeid predators. In: Helle, W. and Sabelis, M. W. (Eds.), Spider Mites: Their Biology, Natural Enemies and Control, vol. 1B, Elsevier, Amsterdam, the Netherlands, 197-203.

Smiley, R. L. 1992. The predatory mite family Cunaxidae (Acari) of the world, with a new classification. Indira Publishing House, West Bloomfield, Michigan, USA, 356pp.

Zaher, M. A. 1986. Survey and Ecological Studies on Phytophagous, Predaceous and Soil Mites in Egypt. II-A: Predaceous and Nonphytophagous Mites (Nile Valley and Delta). PL 480 Programme U.S.A., Project No. EG-ARS-30, Grant No. FGEG-139, 567 pp. 